\title{
Diaphragmatic Lymph Node
}

National Cancer Institute

\section{Source}

National Cancer Institute. Diaphragmatic Lymph Node. NCI Thesaurus. Code C132391.

Lymph node located adjacent to the diaphragm. 